\title{
A COMPARATIVE STUDY OF EMPLOYMENT SERVICES IN GREAT BRITAIN AND TURKEY
}

\author{
ÖZLEM ÖZKANLI
}

\begin{abstract}
This article critically compares the institutions and procedures for the employment services of Great Britain (GB) and Turkey. The similarities and differences of two employment organisations, the Department for Education and Employment in GB and the Turkish Employment Organisation, are examined. Data is collected in field study from these organisations, based in London and Ankara, through interviews and observation techniques. Field study in London is financed by the World Bank. After briefly reviewing the background of the organisations, the article then examines the legal framework and the criteria on which comparisons can be based: establishment, organisational structure, activities, tasks and duties. As a conclusion, public employment policy implications for both countries are presented and evaluated.
\end{abstract}

\section{KEYWORDS}

The Employment Services; Jobseeker's Allowance; Private Recruitment Services; Labour Force Training; The Turkish Employment Organisation; The Department of Education and Employment. 


\section{Introduction}

Before Industrial Revolution, the services of employment in Europe were carried out by firms seeking for profit and charitable foundations. When trade unions were established in developed countries in $19^{\text {th }}$ Century, employment services were started to be carried out by trade unions. Later, these services were considered as public duty and municipalities took the responsibility. "Employment Bureau" under the co-ordination of municipalities were established.

The first official employment organisation was founded in England in 1909. Later, they became widespread in other European countries. In 1919, the duties of Employment Organisations in the world were examined in the Washington Meeting of International Labour Organisation. In the second article and the second contract of ILO, free employment services under the control of central administration were decided and registered.

Today, employment organisations which appear in mainly industrialised northern countries provide three main services suitable to the needs of the century. The first one is employment services, the others are active and passive work force programmes. Active work force programmes aim at educating unqualified workforce and career development. The most important passive work force programme is unemployment insurance. When employment organisations in OECD countries are examined, it can be seen that the employment services, which is the traditional function of these organisations, are decreased, and active and passive work force services are increased.

Before an employment organisation is established in Turkey, employment services differed in each work branch. Workers knew each other, the personnel demand was met by personal relations in small enterprises. Big enterprises, on the other hand, found their personnel by hanging up advertisements on shop windows and other places in the city. Later, for a long time, mediation procedures were carried out by worker commission agents in return for material benefit. After the foundation of the Republic, it was decided to establish an employment organisation in 1946 to prevent exploitation. 


\section{The Turkish Employment Organisation}

\section{a. Establishment}

Following the initial introduction of Labour Law No. 3008 of 1936, facilitating the employment services as a public work, the Turkish Employment Organisation (TEO) was appointed with this task by Act No. 4837, dated 25 January $1946 .{ }^{1}$ The Decree Having Force of Law Establishing Turkish Employment Organisation and Ammending Some Other Acts and Decrees Having Force of Law was approved on 4 October $2000 .^{2}$ Connected to the Ministry of Labour and Social Security, the TEO is a state organisation with administrative and financial autonomy and subject to private law.

\section{b. Organisation}

According to the Reorganisation Project in TEO, the new organisation chart was adopted on 4 October $2000,{ }^{3}$ which can be seen at Figure 1. Besides, TEO has a "Vocational Rehabilitation Centre" for the handicapped established in Ankara and a "Training Centre" established for in-service training in Söke.

\section{c. Tasks and Duties}

In line with the terms and conditions of the Institutional Act of TEO, Labour Law No. 1475, the Act Reputating Privatisation Applications and Ammanding Some Other Acts and Decrees Having Force of Law, the Law No. 4447 related to unemployment insurance, the Constitution, the Institutional Act of the Ministry of

\footnotetext{
1"The Institutional Act of Turkish Employment Organisation", Act No. 4837, Resmi Gazete, 25/1/1946, No. 6215, 3/27, 1946, pp. 842-844.

2"The Decree Having Force of Law Establishing Turkish Employment Organisation and Ammending Some Other Acts and Decrees Having Force of Law", No. 617, Resmi Gazete, 4/10/2000, No. 24190, 2000, pp. 82104.

3Ibid., p.104.
} 
Labour and Social Security and other related laws, ${ }^{4}$ the duties of TEO are:

- Functioning as an intermediary in placement of workers to appropriate jobs and finding appropriate workers for various vacancies;

- Functioning as an intermediary in the conclusion of service contracts;

- Collecting information about all types of economic enterprises and jobs qualified as craftsmanship;

- Obtaining and publishing statistical data concerning the jobseekers, vacancies, placements and establishments;

- Following usage levels through conducting labour market studies, making comparisons between wage levels and living standards (welfare ratios) and assisting in the application of relevant measures to prevent social distress;

- Conducting job and occupation analysis; defining, classifying and coding occupations;

- Providing guidance services so as to ensure the efficient use of human resources and that the labour force work in jobs suitable to their skills;

- Providing job insertion training, retraining and basic training services to the unemployed so as to meet the need of qualified workers available in the labour market;

- Providing assistance towards the employment of exconvicts and the handicapped; conducting vocational rehabilitation services for the handicapped;

\footnotetext{
4"Labour Law", No. 1475, Resmi Gazete, 1/9/1971, No. 13943, 5/10, 1971, pp. 3102-3133; "The Act Reputating Privatisation Applications and Ammending Some Other Acts and Decrees Having Force of Law", Act No. 4046, Resmi Gazete, 27/11/1994, No. 22124, 5/34, 1994, pp. 49-67; "The Law of Unemployment Insurance", No. 4447, Resmi Gazete, 8/9/1999, No. 23810, 1999, pp. 138-146; The Constitution, 1982, Paragraph 49; "The Institutional Act of the Ministry of Labour and Social Security", No. 4841, Paragraph 1 and Paragraph 10, 1970,pp. 1-10.
} 
- In accordance with the Act No. 3713 and the relevant regulations, ${ }^{5}$ ensuring the employment of the relatives of the civil servants, soldiers and non-commissioned officers who were killed or became disabled (those not able to work any longer) or who are disabled due to acts of terrorism;

- In line with the Act No. 4046,6 facilitating the privatisation procedures, following services are provided for workers affected by privatisation:

- Payment of unemployed benefit; Finding new jobs; Providing retraining and vocational training services; Depositing social insurance premiums to the relevant organisations on behalf of the unemployed.

- According to the Unemployment Insurance Act No. $4447,{ }^{7}$ to insure unemployed for providing unemployment appropriations; Payment of health and maternity insurance; Finding new jobs; Providing retraining and vocational training services.

\section{d. Activities}

The activities of Turkish Employment Organisation concerning domestic placements, placements abroad, vocational training and labour market information are presented as follows: ${ }^{8}$

5"Terrorism Preventation Act", Act No. 3713, 1985, pp. 35-40.

6"The Act Reputating Privatisation Applications and Ammending Some Other Acts and Decrees Having Force of Law", Act No. 4046, Resmi Gazete, 27/11/1994, No. 22124, 5/34, 1994, pp. 58-59.

7"The Law of Unemployment Insurance", No. 4447, Resmi Gazete, 8/9/1999, No. 23810, 1999 , pp. 58-59.

${ }^{8}$ The Turkish Employment Organisation Statistical Yearbook, Issue No.: 308, Ankara, The Turkish Employment Organisation, 2000. 


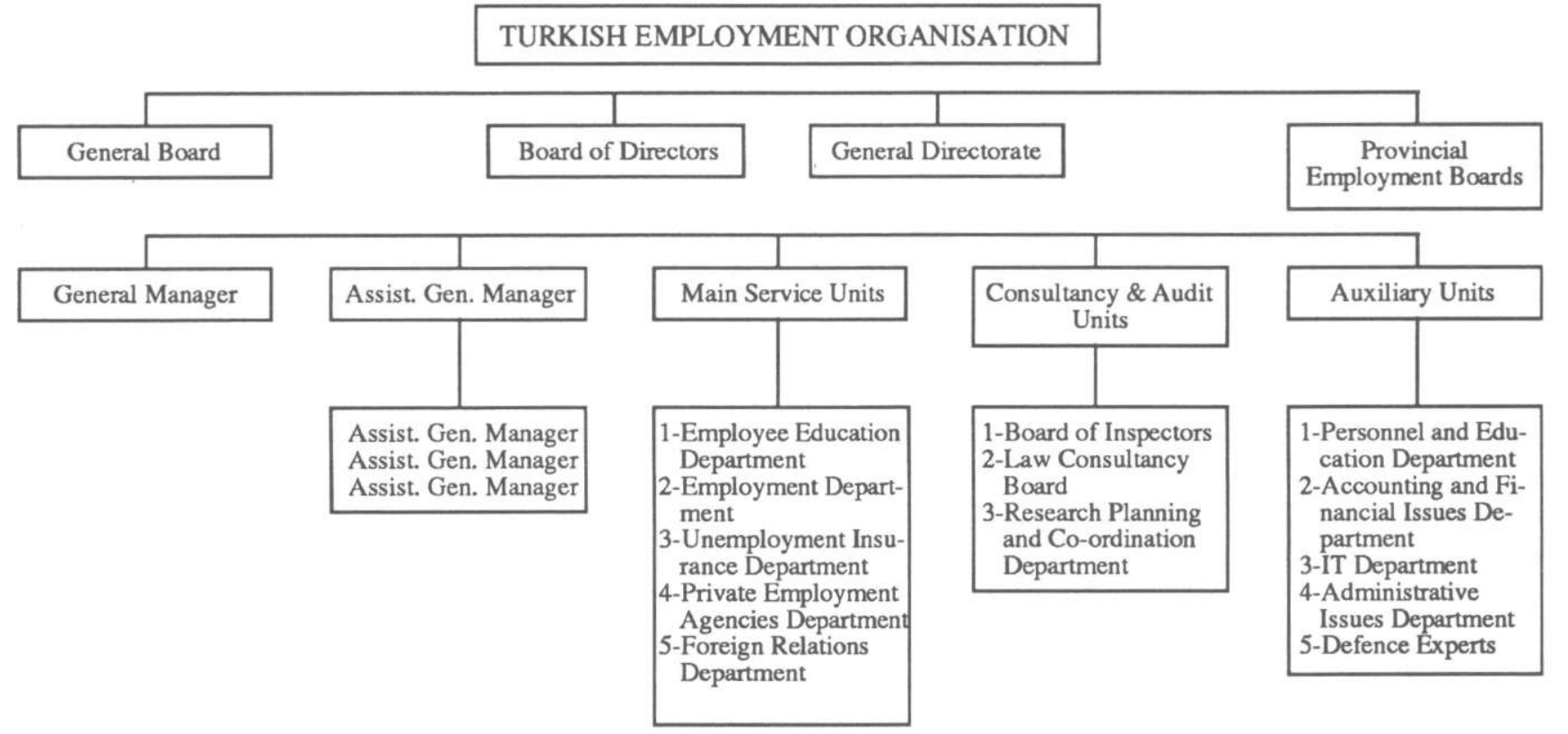

Source: "The Decree Having Force of Law Establishing Turkish Employment Organisation and Ammending Some Other Acts and Decrees Having Force of Law", No. 617, Resmi Gazete, 4/10/2000, No. 24190, 2000, p. 104. 


\section{i. Domestic Placements}

Since 1946, the TEO has accomplished an important task in providing solutions for labour and unemployment problems and meeting the labour force demand required by the national economy. Since its establishment, as of the end of 1999, out of 26.964.837 jobseekers who have applied to the TEO, a total of 14.938.717 have been placed domestically. Presently, the TEO accomplishes domestic placements of approximately 200-250 thousand people in a year, while also making 30-35 thousand placements abroad.

While the average age of people placed between 1946 and 1999 by the TEO ranges between the age groups of $20-24$ and $25-$ 29 ; regarding the education levels of those placed, the majority consist of the primary, secondary and high school graduates.

Within 1999, a total number of 435.193 applications were made; a total of 222.444 vacancies from private and public sector were received and 201.942 placements were accomplished.

\section{ii. Placements Abroad}

The migration of labour force to West European countries which started on individual basis during the 1950s and was legally recognised with the signing of Labour Force Agreement with Germany in 1961, accelerated until 1974, and declined afterwards.

In order to protect the labour rights of the workers placed, bilateral agreements concerning labour force have been concluded with Germany, Austria, Netherlands, Belgium, France, Sweden, Australia, Libya, Jordan and the Turkish Republic of Northern Cyprus.

Out of a total of 4.048 .499 applications made for job placements abroad 1.810.686 were met between 1961 and 1999 . In 1999 , a total of 17.745 workers were placed abroad by the TEO.

Furthermore, in line with the "Agreement Related to the Employment of the Workers of Turkish Firms in the Framework of the Exclusion Contract" signed with Germany in 1991, the Turkish 
construction firms contracting in Germany were provided with the right to locate their own workers with short term services contracts. These workers were located in Germany by 376 Turkish firms contracting in this country; some of them returned with the completion of works undertaken, while 885 Turkish workers still work in Germany.

\section{iii. Vocational Training}

\section{- Retraining}

Having been conducting activities of archive establishment, literature search, provision of labour market information and testing since 1972, the TEO has initiated job and career counselling services in 1991 as a result of the co-operation made with German Labour Organisation.

Job and career counselling services are based on systematic collection, evaluation and presentation of vocational data. In this context, "Job and Career Counselling Units" were established in Ankara, İstanbul, Bursa, İzmir and Adana local offices and a "Career Information Centre" was also organised in Ankara.

In 1999, vocational orientation/retraining services were provided in 166 schools by these units; a total of 18,865 students were interviewed in groups and career counselling services were provided for 3510 individuals.

In addition, "Career Information Centres" have been established in 7 local offices throughout 1999 and since 31 December 1999, 39 local offices have been providing career counselling services. In 1999, a total of 22.375 people were served in the centres through individual or group sessions organised.

\section{- Labour Force Training}

The TEO organises labour force training courses so as to provide training for the unemployed without any vocational knowledge and skills in the jobs demanded by the labour market. Labour force training courses are classified in four groups; 
Employment Guaranteed Courses aim to deliver training to the unemployed registered by the TEO, who do not have any jobs or any jobs valid in the labour market in the occupations demanded by the labour market.

Self-Employment Training Courses are organised for the registered unemployed by the TEO, who want to be self-employed in a different occupation or who wish to improve their original skills.

Vocational Development Courses aim to increase the qualifications of those who are registered as having a vocation, in accordance with the requirements of the labour market and thus providing them employment.

Vocational Rehabilitation Courses aim to assist the disabled who do not have any occupation, to acquire vocational skills and knowledge in line with their needs and aptitudes and thus making their employment easier.

Table 1: Labour Force Training Courses

\begin{tabular}{|c|c|c|}
\hline YEARS & \multicolumn{2}{|c|}{ TRAINING COURSES } \\
\hline & \# of Courses & \# of Participants \\
\hline 1988 & 62 & 961 \\
\hline 1989 & 337 & 5907 \\
\hline 1990 & 697 & 11790 \\
\hline 1991 & 821 & 13867 \\
\hline 1992 & 470 & 8069 \\
\hline 1993 & 628 & 11536 \\
\hline 1994 & 841 & 15695 \\
\hline 1995 & 1092 & 20037 \\
\hline 1996 & 611 & 11426 \\
\hline 1997 & 608 & 10753 \\
\hline 1998 & 496 & 9742 \\
\hline 1999 & 222 & 4384 \\
\hline TOTAL & $\mathbf{6 8 8 5}$ & $\mathbf{1 2 4 1 6 7}$ \\
\hline
\end{tabular}

Source: The Turkish Employment Organisation Statistical Yearbook, Issue No. 308, Ankara, 2000, p. 10. 


\section{- Training at Industry}

Training at the industry for labour in employment activities include relations among people at the workplace, communication, simplification of work, productivity, work hazards and safety. Training activities at the industry are classified into three groups:

Worker Improvement Seminars aim to improve the productivity of the workers, the quality of the work done and to provide assistance for the solution of the problems that may arise among workers.

First Level Management Seminars aim to improve the management and instructional skills of foreman, supervisors, inspectors, etc., and their assistants who constitute the first level of management in the enterprises.

Middle Level Management Seminars aim to prove the management and instructional skills of technicians, division chiefs, engineers, branch managers, etc., who constitute the middle level management.

Within the 13-year period starting from 1988 until the end of 1999,1087 industry seminars were organised at 425 enterprises with the attendance of 25,098 people, the majority being workers.

Table 2: Training at Industry Seminars

\begin{tabular}{|c|c|c|c|}
\hline YEA RS & \multicolumn{3}{|c|}{ SEMINARS } \\
\hline & \# of Enterprises & \# of Seminars & $\#$ of Participants \\
\hline 1988 & 30 & 40 & 758 \\
\hline 1989 & 36 & 53 & 1077 \\
\hline 1990 & 37 & 73 & 1579 \\
\hline 1991 & 26 & 67 & 1479 \\
\hline 1992 & 16 & 50 & 1467 \\
\hline 1993 & 20 & 47 & 992 \\
\hline 1994 & 29 & 108 & 2790 \\
\hline 1995 & 38 & 83 & 1859 \\
\hline 1996 & 42 & 135 & 3132 \\
\hline 1997 & 52 & 179 & 4159 \\
\hline 1998 & 55 & 151 & 3613 \\
\hline 1999 & 44 & 101 & 2193 \\
\hline TOTAL & $\mathbf{4 2 5}$ & $\mathbf{1 0 8 7}$ & $\mathbf{2 5 0 9 8}$ \\
\hline
\end{tabular}


Source: The Turkish Employment Organisation Statistical Yearbook, Issue No. 308, Ankara, 2000, p. 11.

\section{iv. Labour Market Information}

Activities concerning the monitoring of labour market are also being conducted by the TEO. The following are the periodic publications related to the labour market:

employment data;

- Employment Report covering annual evaluation of

- Statistical Yearbook and Monthly Statistical Bulletin including general data on labour market.

\section{v. Unemployment Benefit}

Under the Privatisation Act No. $4046,{ }^{9}$ which facilitates activities related to the preparation for privatisation, downsizing, partial or integral suspension of activities, closure or partial closure or liquidation of the enterprises whose service contracts are terminated and who are legally eligible to receive unemployment benefit, are also provided by the TEO.

In accordance with the Act mentioned above, during the period between 1 March 1995 and 31 December 1999, unemployment benefit payments were made to 10.451 workers out of a total of 11.001 applications, in addition to the social security premiums paid.

\section{vi. The Law of Unemployment Insurance}

The Law of Unemployment Insurance, No. 4447, approved on 25 August 1999, put into force on 1 June 2000 on the country level. According to the Law, the rate of premium payment to

9"The Act Reputating Privatisation Applications and Ammending Some Other Acts and Decrees Having Force of Law", Act No. 4046, Resmi Gazete, 27/11/1994, No. 22124, 5/34, 1994, pp. 58-59. 
contribute to the system will be $\% 2$ for workers, $\% 3$ for employers and $\% 2$ for the state. ${ }^{10}$

Furthermore, an Unemployment Insurance Fund is formed, to be governed by the Executive Committee with members of two public administration representatives, one worker representative and one employer representative, to provide financial source for duty and services as required by unemployment insurance, to evaluate sources according to market conditions and to make payments projected. The fund will be inspected by the Supreme Council of Investigation of the Prime Ministry, besides, the income and expense will be inspected by certified financial advisor and the results of inspection report will be announced to public.

The payment of unemployment appropriations of insured unemployed will be started after the end of 600 days ( 20 months) of premium payment, starting from March 2002, for the implementation of unemployment insurance started on 1 June 2000 .

There are some recruitment agencies in Turkey, but the legal basis of their activities is recent. The Decree Having Force of Law Establishing Turkish Employment Organisation and Ammending Some Other Acts and Decrees Having Force of Law No. 617 on 4 October 2000 explains the tasks and duties of them. Table 3 shows the general activities of Turkish Employment Organisation.

Table 3: General Activities of Turkish Employment Organisation

\begin{tabular}{|c|c|c|c|c|c|c|c|}
\hline YEARS & \multicolumn{5}{|c|}{ DOMESTIC SERVICES } & \multicolumn{2}{c|}{$\begin{array}{c}\text { FOREIGN } \\
\text { SERVICES }\end{array}$} \\
\hline & Applications & Vacancies & Placements & Unemployed & $\begin{array}{c}\text { Company } \\
\text { Visits }\end{array}$ & Applications & Send \\
\hline 1948 & 43952 & - & - & - & - & - & - \\
\hline 1949 & 48092 & - & - & - & - & - & - \\
\hline 1950 & 54710 & - & - & - & - & - & - \\
\hline 1951 & 79650 & 55343 & 28074 & - & - & - & - \\
\hline 1952 & 135965 & 117290 & 63494 & - & - & - & - \\
\hline 1953 & 257203 & 270570 & 194862 & - & - & - & - \\
\hline 1954 & 412360 & 440863 & 356547 & - & - & - & - \\
\hline 1955 & 518896 & 538408 & 454527 & - & - & - & - \\
\hline
\end{tabular}

10 "The Law of Unemployment Insurance", No. 4447, Resmi Gazete, 8/9/1999, No. 23810, 1999, pp. 58-59. 


\begin{tabular}{|c|c|c|c|c|c|c|c|}
\hline \multirow[t]{2}{*}{ YEARS } & \multicolumn{5}{|c|}{ DOMESTIC SERVICES } & \multicolumn{2}{|c|}{$\begin{array}{l}\text { FOREIGN } \\
\text { SERVICES }\end{array}$} \\
\hline & Applications & Vacancies & Placements & Unemployed & $\begin{array}{c}\text { Company } \\
\text { Visits } \\
\end{array}$ & Applications & Send \\
\hline 1956 & 599808 & 600736 & 521629 & - & - & - & $=$ \\
\hline 1957 & 643904 & 627922 & 562392 & - & - & - & - \\
\hline 1958 & 610599 & 592103 & 542962 & - & - & - & - \\
\hline 1959 & 639443 & 598611 & 549594 & - & - & - & - \\
\hline 1960 & 688038 & 603544 & 574270 & - & - & - & - \\
\hline 1961 & 5734 & 3 & 26 & 12442 & 14946 & 45050 & 1476 \\
\hline 1962 & 560392 & 426589 & 35 & 17846 & 101098 & 77495 & 11185 \\
\hline 1963 & 545154 & 406292 & 5081 & 21460 & 98537 & 143424 & 30328 \\
\hline 1964 & 480170 & 346070 & 313968 & 23507 & 78800 & 322102 & 66176 \\
\hline 1965 & 427012 & 278688 & 258070 & 22536 & 81665 & 333449 & 51520 \\
\hline 1966 & 435958 & 286224 & 263292 & 23459 & 96492 & 119151 & 34410 \\
\hline 1967 & 468054 & 305176 & 286531 & 26789 & 165467 & 105323 & 8947 \\
\hline 1968 & 548798 & 365752 & 348771 & 33028 & 131181 & 126725 & 43204 \\
\hline 1969 & 575452 & 369159 & 355463 & 39040 & 120186 & 253946 & 103975 \\
\hline 1970 & 559914 & 346782 & 333988 & 43788 & 118708 & 371959 & 129575 \\
\hline 1971 & 579935 & 379594 & 367284 & 44946 & 132835 & 267403 & 77442 \\
\hline 1972 & 612 & 423943 & 770 & 43886 & 127092 & 202510 & 85229 \\
\hline 1973 & 58 & 4 & 4 & 65 & 52 & 263608 & 135820 \\
\hline 1974 & 663965 & 4. & 26 & 8 & 993 & 7090 & 20211 \\
\hline 1975 & 601110 & 356811 & 337548 & 116766 & 116577 & 125546 & 4419 \\
\hline 1976 & 848657 & 411468 & 385405 & 141275 & 165702 & 23798 & 10558 \\
\hline 1977 & 826844 & 405237 & 376834 & 131439 & 96371 & 34950 & 19084 \\
\hline 1978 & 832265 & 318130 & 296925 & 152954 & 84508 & 40174 & 18852 \\
\hline 1979 & 653581 & 235069 & 211531 & 189467 & 74036 & 50627 & 23630 \\
\hline 1980 & 504780 & 189368 & 163426 & 263354 & 67405 & 40442 & 28503 \\
\hline 1981 & 618137 & 201366 & 161048 & 341336 & 30926 & 58656 & 58753 \\
\hline 1982 & 639142 & 188946 & 151278 & 468654 & 55707 & 0 & 49388 \\
\hline 1983 & 648837 & 200472 & 158042 & 626175 & 49128 & 95890 & 52470 \\
\hline 1984 & 117 & 214415 & 178018 & 963589 & 38885 & 142948 & 45815 \\
\hline 1985 & 512590 & 170002 & 157690 & 966195 & 43478 & 55370 & \begin{tabular}{|l}
47353 \\
\end{tabular} \\
\hline 1986 & 580109 & 275235 & 258848 & 1081306 & 57674 & 55141 & 35068 \\
\hline 1987 & 482087 & 262416 & 253449 & 1134884 & 58256 & 77171 & 40807 \\
\hline 1988 & 400320 & 254938 & 251120 & 1162548 & 51641 & 151651 & 53021 \\
\hline 1989 & 552779 & 282842 & 266874 & 1009840 & 53122 & 28604 & 49928 \\
\hline 1990 & 672110 & 293742 & 283243 & 896132 & 79236 & 12190 & 47707 \\
\hline 1991 & 691450 & 269081 & 269577 & 825567 & 76418 & 326139 & 53020 \\
\hline 1992 & 814544 & 301355 & 297765 & 775901 & 52944 & 9892 & 60000 \\
\hline 1993 & 546604 & 278715 & 267088 & 609119 & 45997 & 2789 & 63244 \\
\hline 1994 & 362666 & 251017 & 242466 & 469345 & 47665 & 1769 & 61145 \\
\hline 1995 & 335787 & 272707 & 264111 & 401292 & 44068 & 2402 & 59483 \\
\hline 1996 & 4111170 & 267060 & 243180 & 416795 & 47618 & 2299 & 40697 \\
\hline 1997 & 468070 & 238539 & 220615 & 463323 & 45727 & 519 & 33321 \\
\hline 1998 & 430407 & 235360 & 218354 & 465235 & 43333 & 164 & 25907 \\
\hline 1999 & 435193 & 224444 & 201942 & 487525 & 41582 & 133 & 17475 \\
\hline
\end{tabular}

Source: The Turkish Employment Organisation Statistical Yearbook, Issue No. 308, Ankara, 2000, p. 4. 


\section{The Department for Education and Employment}

The Department for Education and Employment (DfEE) is the UK Government Department with the overall aim to give everyone the chance through education, training and work, to realise their full potential and thus build an inclusive and fair society and a competitive economy.

The DfEE is working with others, in Government and beyond, towards two overarching goals:

- an inclusive society, where everyone has an equal chance to achieve their full potential;

- a globally competitive economy with successful firms and a fair and efficient labour market. ${ }^{11}$

The Department makes its distinctive contribution by concentrating on three central objectives; ${ }^{12}$

1) Ensuring that all young people reach the age of 16 with the skills, attitudes and personnel qualities that will give them a secure foundation for lifelong learning, work and citizenship in a rapidly changing world. This will be achieved in particular by substantially improving literacy and numerical skills in primary schools, pupil achievement in secondary schools and support for the family through early education and the availability of affordable good quality childcare in every neighbourhood.

2) Developing in everyone a commitment to lifelong learning so as to enhance their lives, improve their employability in a changing labour market and create the skills that UK economy and employees need. This will be achieved in particular by making learning attractive and accessible, improving the relevance and quality of provision and persuading employers to invest in those they employ.

\footnotetext{
${ }^{11}$ For more information see, Department of Education and Employment (DfEE) website at [http://www.dfee.gov.uk].

${ }^{12}$ The Department of Education and Employment Departmental Report, London, The Department of Education and Employment Publication,The Stationary Office Limited, April 2000, pp. 8-9.
} 
3) Helping those without a job into work; in particular by helping young people, the long-term unemployed and others at a disadvantage in the labour market, including lone parents, to move into sustainable jobs, within a fair and diverse employment market.

The Employment Service of DfEE is responsible for the third objective, which is similar to the objectives of the Turkish Employment Organisation. In Turkey this organisation is connected to the Ministry of Labour and Social Security. The Ministry of Education in Turkey covers the first and second objectives of the DfEE. Therefore, in this study, only the Employment Service is going to be explained in details.

Figure 2 shows the organisational chart of Department of Education and Employment.

\section{a. The Employment Service}

The Employment Service (ES) is an Executive Agency within the DfEE. The aim of the ES is to help people without jobs to find work and employers to fill their vacancies. Within this overall aim the Employment Service has the following key objectives: ${ }^{13}$

- to help all people without jobs and particularly those on welfare and at a disadvantage in the labour market to find and keep work by providing appropriate information, advice, training, support and by encouraging employers to open more opportunities to them;

- to ensure that the rights and relevant labour market responsibilities of people on Jobseeker's Allowance (JSA) and other benefits are fulfilled, while helping to combat fraud and abuse of the benefit system;

${ }^{13}$ The Employment Service Operational Plan, London, The Employment Service Publication, 2000, p. 19. 

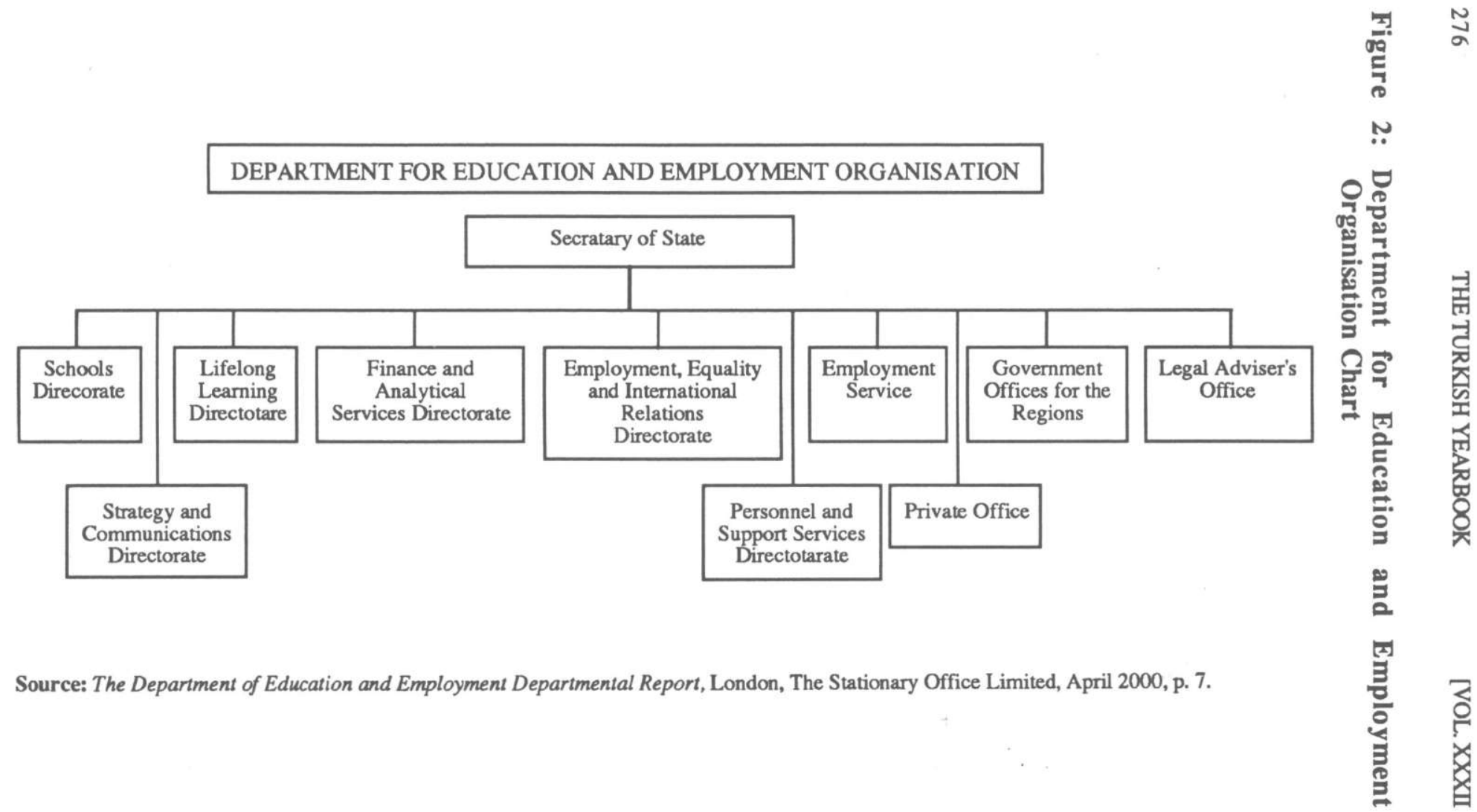

Source: The Department of Education and Employment Departmental Report, London, The Stationary Office Limited, April 2000 , p. 7. 
- to harness new technology and pursue continuous improvement to deliver effective, efficient and accessible services to all people without jobs and to employers in Jobcentres and increasingly, through other locations and means of communication; and

- to deliver services to all ES customers in a way which respects individual differences helps to overcome disadvantages due to ethnicity, gender, age or disability and achieves the best possible outcome for each of them.

The ES is led by its Chief Executive who is responsible to the Secretary of State for Education and Employment. Each year the Secretary of State sets targets for the Agency. The ES Head Office is organised into four Directorates. Their Directors and the Chief Executive comprise the ES Board, on which also sit two nonexecutive Directors. The ES Head Office works closely with colleagues from the Department for Education and Employment (Figure 3).

The ES delivers its services to customers primarily through its network of about 1100 local Jobcentres. Each Jobcentre is led by a business manager and depending on its size and location, may have between 10 and 100 staff. The services provided by them to jobseekers and employers include, displaying employers' job vacancies and ensuring these are up to date; matching jobseekers to vacancies and providing assistance in job search; taking new claims for Jobseeker's Allowance; giving advice and guidance to unemployed people, particularly long term unemployed people; arranging access to specialist services for jobseekers with disabilities; and providing information on local unemployment and training opportunities. ${ }^{14}$

The ES computer system keeps track of all job vacancies that are notified to ES Jobcentres. In 1999-2000 Jobcentres handled 2.7 million vacancies; submitted 22 million people to job vacancies; placed some 1.4 million people into work; placed 438.000 people into training and employment programs; took

\footnotetext{
${ }^{14}$ The Employment Service Booklet, London, The Employment Service Publication, 2000, p. 5.
} 


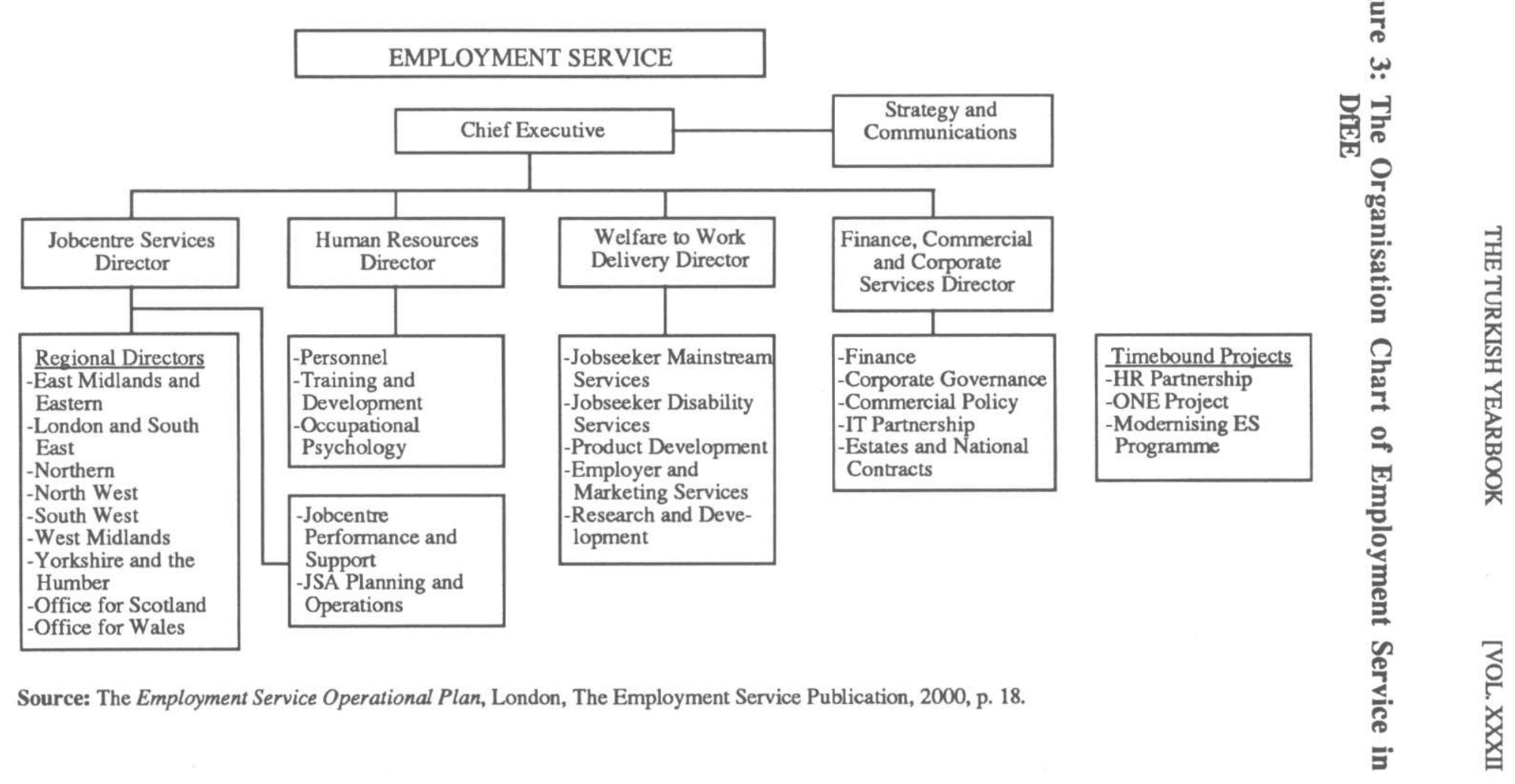


3.04 million new claims; and placed over 96.000 people with disabilities into jobs. ${ }^{15}$

The ES works closely with other organisations to help unemployed people. It also has a number of partnerships with private sector organisations which deliver services to it under contract. These include all IT services, facilities management services, payroll and human resource services and management training.

The ES offers help for unemployed people, particularly those who are long-term unemployed, people with disabilities and others who may need extra support. The core of this help comprises fortnightly interviews in Jobcentres for all unemployed people who claim the Jobseeker's Allowance, which is the benefit for unemployed people of working age who are available for and actively seeking work. The ES and the Benefits Agency work closely together to deliver JSA through Jobcentres. ES staff are responsible for checking that jobseekers meet the labour market conditions attached to JSA. Benefits Agency staff are responsible for calculating and delivering JSA payments- often working in Jobcentres alongside ES staff.

To receive JSA, the jobseekers complete a Jobseeker's Agreement, which they and an ES adviser sign jointly. This outlines a plan of action for getting back into work. The jobseekers must visit the Jobcentre in person at least every fortnight to discuss their jobsearch activity with an ES adviser. After six months of unemployment, an in-depth interview takes place and the jobseekers become eligible for a wider range of help in finding work. The details of help (training, work trials, help with travel costs to attend job interviews, intensive jobsearch activity, etc.) available change regularly in the light of evaluation. Similar reviews continue every six months, as long as the jobseekers remain unemployed.

Special help is also available for people with a disability. ES employs specialist Disability Employment Advisers, based in jobcentres, who work with individuals in detail. The current range of help includes, grants towards the cost of extra support or

${ }^{15}$ Labour Market Trends, October, London, n.p., 2000, p. 437. 
equipment needed to enter or stay in employment; contribution towards employers' costs in employing a person with a disability; and supported employment for those with severe disabilities return to work. ${ }^{16}$

Most ES programmes offer early entry to jobseekers with disabilities, those returning to the labour market and those who have newly left the armed forces or have recently been released from prison.

The ES is committed to equality of opportunity and continues to work to ensure that its programmes and services are as accessible as possible to all jobseekers irrespective of sex, marital status, race, colour, nationality, ethnicity, disability, age, religion or sexual orientation.

Helping people to move from welfare into work is a priority for the British Government. The ES is the lead organisation of this "Welfare to Work" programme. In addition to these, the New Deals and Employment Zones programmes offer intensive support to help people find and keep employment. The New Deals for Partners of the Unemployed and for the over 50s have been added to the initiatives for young people, the over $25 \mathrm{~s}$, people with disabilities and lone-parents. Working closely with the Department of Social Security (DSS), DfEE is building on this approach by developing the ONE service.

\section{i. New Deals}

-New Deal for unemployed people aged 18-24 who have been out of work for more than six months was introduced nationally in April 1998.

-New Deal for jobseekers aged 25 plus who have been out of work for more than two years was introduced nationally in June 1998 and enhanced from April 2000 onwards.

\footnotetext{
${ }^{16}$ The Employment Service Booklet, London, The Employment Service Publication, 2000, p. 19.
} 
-New Deal 50 plus is designed to improve the position of older people in the labour market and offers financial help for this age group.

-New Deal for people with disability is being developed on a pilot basis for people of working age receiving incapacity benefits, with Employment Service and Benefits Agency working closely to deliver a Personnel Adviser Service.

-New Deal for lone-parents helps with Income Support to take up or increase paid work.

-New Deal Personal Advisers also offer help to partners of JSA claimants, who are themselves out of work.

\section{ii. ONE}

ONE is a new service, delivered through partnership of the ES, the Benefits Agency, local authorities and in some areas, the private and voluntary sectors. It offers jobseekers information on work, benefits and other government services.

A Personnel Adviser assesses individuals' needs and works with them to plan a pathway towards independence through work where this is practical, identifying and seeking to remove clients' barriers to securing jobs. country.

At present ONE is running in 12 pilot areas around the

\section{iii. Employment Zones}

The British Government is encouraging innovative approaches to tackle unemployment in fifteen areas of the country. The provision in these Employment Zones is delivered by partnerships of public, voluntary and private sector organisations, under contract to Government. As well as exploring new ideas, partnerships are encouraged to use funding in a more effective and coherent way. 
The Employment Service is involved with all the Employment Zones, since it liases with the organisations which run them.

Table 4: Total Expenditure on Employment Measures in Great Britain (£ million)

\begin{tabular}{|l|c|c|c|c|}
\hline & $\begin{array}{c}1998-1999 \\
\text { outturn }\end{array}$ & $\begin{array}{c}1999-2000 \\
\text { outturn }\end{array}$ & $\begin{array}{c}2000-2001 \\
\text { plans }\end{array}$ & $\begin{array}{c}2001-2002 \\
\text { plans }\end{array}$ \\
\hline Employment Service & 1098 & 1141 & 1171 & 1493 \\
\hline New Deal & 220 & 428 & 613 & 581 \\
\hline DfEE Programmes & 281 & 316 & 394 & 80 \\
\hline Value Added Tax & 20 & 35 & 26 & 26 \\
\hline Total & $\mathbf{1 6 1 9}$ & $\mathbf{1 9 2 0}$ & $\mathbf{2 2 0 4}$ & $\mathbf{2 1 8 0}$ \\
\hline
\end{tabular}

Source: DfEE Departmental Report, London, The Stationery Office Limited, April 2000, p.124.

The effectiveness of ES is measured through a number of targets which are published annually, along with the aim and objectives of ES, in the Employment Service Annual Performance Agreement. Building on steps taken in 1998-1999 to improve performance, the ES job placing targets were above profile by the end of January 2000.

Table 5: Annual Performance Agreement Targets: Placing Performance (000s) ${ }^{1}$

\begin{tabular}{|l|c|c|c|}
\hline & $\begin{array}{c}1998-1999 \\
\text { Target }\end{array}$ & $\begin{array}{c}1998-1999 \\
\text { Outturn }\end{array}$ & $\begin{array}{c}1999-2000 \\
\text { Target }\end{array}$ \\
\hline Total unemployed placing & 1300 & 1223 & $1250^{2}$ \\
\hline Long-term JSA claimant placing & 250 & 180,8 & $190^{2}$ \\
\hline Two year plus JSA Claimant Placing & 60 & 36,8 & $38^{2}$ \\
\hline $\begin{array}{l}\text { Placing of New Deal 18-24 year old } \\
\text { participants into work }\end{array}$ & 100 & 69,6 & $100^{2}$ \\
\hline $\begin{array}{l}\text { Placing of New Deal for lone parents } \\
\text { participants into work }\end{array}$ & No target & n/a & $15^{2}$ \\
\hline $\begin{array}{l}\text { Placing of unemployed people with } \\
\text { disabilities into work }\end{array}$ & 80 & 99,5 & $85^{2}$ \\
\hline
\end{tabular}

${ }^{1}$ Performance targets for 2000-2001 will be published in the 2000-2001 Employment Service Annual Performance Agreement.

2Performance against this target will be published in the Employment Service Annual Report and Accounts.

Source: DfEE Departmental Report, London, The Stationery Office Limited, April 2000, p.125. 


\section{iv. Employment Action Teams}

Action Teams have been set up in 20 of Britain's communities with the highest unemployment and lowest employment with additional support available in the 15 Employment Zone areas. The programme is worth $£ 40$ million. Small, flexible teams, bringing together the public service, private and voluntary sectors, will use the funding to tackle local barriers to employment, help employers with hard-to-fill vacancies and link vacancies to people who are not working but are able to.

Table 6: New Deal: Employment Service Running and Programme Costs (£million)

\begin{tabular}{|c|c|c|c|c|}
\hline & $\begin{array}{c}\text { 1998-1999 } \\
\text { Outturn }\end{array}$ & $\begin{array}{l}\text { 1999-2000 } \\
\text { Outtum }\end{array}$ & $\begin{array}{l}2000-2001 \\
\text { Plans }\end{array}$ & $\begin{array}{l}\text { 2001-2002 } \\
\text { Plans }\end{array}$ \\
\hline \multicolumn{5}{|l|}{ Running Costs: } \\
\hline $\begin{array}{l}\text { New Deal for Young } \\
\text { People }\end{array}$ & 94 & 73 & 95 & 95 \\
\hline New Deal 25 Plus & 3 & 18 & 22 & 15 \\
\hline $\begin{array}{l}\text { New Deal for Lone } \\
\text { Parents }\end{array}$ & 16 & 25 & 26 & 22 \\
\hline New Deal for Disabled & 1 & 3 & & \\
\hline $\begin{array}{l}\text { New Deal for Partners } \\
\text { of the Unemployed }\end{array}$ & 1 & 6 & 6 & 5 \\
\hline New Deal 50 Plus & 0 & 2 & 7 & 7 \\
\hline $\begin{array}{l}\text { New Deal Innovation } \\
\text { Fund }\end{array}$ & 0 & 0 & 1 & 1 \\
\hline \multicolumn{5}{|l|}{ Programme Costs: } \\
\hline $\begin{array}{l}\text { New Deal for Young } \\
\text { People }\end{array}$ & 79 & 159 & 305 & 330 \\
\hline New Deal 25 Plus & 9 & 116 & 108 & 64 \\
\hline $\begin{array}{l}\text { New Deal for Lone } \\
\text { Parents }\end{array}$ & 1 & 10 & 17 & 12 \\
\hline New Deal for Disabled & & 1 & & \\
\hline $\begin{array}{l}\text { New Deal for Partners } \\
\text { of the Unemployed }\end{array}$ & 0 & 2 & 12 & 11 \\
\hline New Deal 50 Plus & 0 & 1 & 9 & 9 \\
\hline $\begin{array}{l}\text { New Deal Innovation } \\
\text { Fund }\end{array}$ & & 0 & 1 & 6 \\
\hline Total & 204 & 416 & 609 & 577 \\
\hline Capital Costs & 12 & 3 & & \\
\hline
\end{tabular}

Source: DfEE Departmental Report, London, The Stationery Office Limited, April 2000, p.128. 


\section{v. Employment Service Programmes}

As well as the New Deals, ES offers a range of measures to meet the needs of those at various stages of unemployment. The programmes include:

- Programme Centres, which operate in around 85 percent of ES districts, replace traditional fixed-length job search courses with a modular approach that addresses the needs of individual jobseekers, so that no two programme centres are exactly alike. There are now 252 programme centres across Great Britain. The remaining ES districts operate a combination of Jobclubs and Jobplan Workshops.

Table 7: New Deal Performance

\begin{tabular}{|l|c|c|}
\hline & $\begin{array}{c}\text { New Deal for } \\
\text { Young People }\end{array}$ & $\begin{array}{c}\text { New Deal 25 } \\
\text { Plus }^{2}\end{array}$ \\
\hline Starts on New Deal & 404,200 & 216,000 \\
\hline Jobs gained & 185,250 & 34,170 \\
\hline Of which: & \multicolumn{2}{|l|}{} \\
\hline Sustained jobs & 135,350 & 28,550 \\
\hline $\begin{array}{l}\text { On Gateway/Advisory } \\
\text { Interview Peocess }\end{array}$ & 60,900 & 70,500 \\
\hline On Options: & \multicolumn{2}{|l|}{} \\
\hline Employer & 10,890 & 4550 \\
\hline Education and Training & 17,780 & 2460 \\
\hline Voluntary Sector & 7120 & - \\
\hline Environment Task Force & 7020 & - \\
\hline $\begin{array}{l}\text { Work Based Learning for } \\
\text { Adults/Training for Work }\end{array}$ & 22,670 & 7180 \\
\hline On Follow Through & \multicolumn{2}{|l}{} \\
\hline
\end{tabular}

${ }^{1}$ New Deal for Young People was introduced nationally on 6 April 1998. Performance figures refer to the period ending December 1999.

${ }^{2}$ New Deal for long-term Unemployed People aged 25 plus was introduced nationally on 29 June 1998. Figures refer to the period ending December 1999.

${ }^{3}$ The Voluntary Sector and Environmental Task Force options refer to New Deal for Young People.

Source: DfEE Departmental Report, London, The Stationery Office Limited, April 2000, p.128. 
- Jobclubs offer, two weeks guidance and training in jobsearch techniques, including telephone and interview skills, curriculum vitae preparation and where to look for job opportunities, followed by practical assistance and ongoing support.

- Jobplan Workshop is a five-day programme of individual assessment, job search guidance and confidence building.

- A Work Trial is a short trial period, up to a maximum of 15 working days, in an actual job vacancy. During this time jobseekers, who have been unemployed for six months or more, have the opportunity to try out the job and show the employer that they are the right person to fill it.

- Jobfinder's Grant is a one-off payment of $£ 200$ which can be claimed by long-term (normally over two years) JSA claimants when they move from unemployment into work.

- The Travel to Interview Scheme is available to people who have been unemployed for 13 weeks or more, with immediate help for victims of large scale redundancies. It encourages people to widen their job search by providing financial assistance so that they can attend interviews beyond normal daily travelling distance. This includes the cost of overnight accommodation where necessary.

The ES aims to deliver a high quality service to both job seekers and employees. Districts covering 382 jobcenters (38\% of total), plus three regional Disability Services offices have "Chartermark" status. The Jobseeker's Charter sets out the standards of service that jobseekers and other customers can expect more widely from the ES and its partners in Jobcenters. ${ }^{17}$ Employer Service Commitments set out minimum standards of service which employers can expect from Jobcenters.

${ }^{17}$ Jobcentre Services Booklet, London, The Employment Service Publication, 2000, p. 19. 
Table 8: Jobsearch Provision Expenditure and Opportunities

\begin{tabular}{|l|c|c|c|c|c|c|c|c|}
\hline & \multicolumn{2}{|c|}{$1998-99$ outturn } & \multicolumn{2}{c|}{$1999-00$ outturn } & \multicolumn{2}{c|}{$2000-01$ plans } & \multicolumn{2}{c|}{$2001-02$ plans } \\
\hline & $\begin{array}{c}\text { Expenditure } \\
(£ \mathrm{~m})\end{array}$ & $\begin{array}{c}\text { Numbers } \\
\text { helped }\end{array}$ & $\begin{array}{c}\text { Expenditure } \\
(£ \mathrm{~m})\end{array}$ & $\begin{array}{c}\text { Numbers } \\
\text { helped }\end{array}$ & $\begin{array}{c}\text { Expenditure } \\
(£ \mathrm{~m})\end{array}$ & $\begin{array}{c}\text { Numbers } \\
\text { helped }\end{array}$ & $\begin{array}{c}\text { Expenditure } \\
(£ \mathrm{~m})\end{array}$ & $\begin{array}{c}\text { Numbers } \\
\text { helped }\end{array}$ \\
\hline $\begin{array}{l}\text { Programme } \\
\text { Centres, } \\
\text { Jobclub and }\end{array}$ & 31.4 & $\begin{array}{c}174,00 \\
0\end{array}$ & 33.0 & 200,000 & 30.1 & 165,700 & 30.1 & 165,700 \\
$\begin{array}{l}\text { Jobplan } \\
\text { Workshops }\end{array}$ & 0.2 & 6,600 & 0.4 & 5,000 & 0.3 & 7,890 & 0.3 & 7,900 \\
\hline Work Trials & 1.9 & 10,700 & 3.9 & 18,500 & 3.3 & 16,500 & & \\
\hline $\begin{array}{l}\text { Jobfinder's } \\
\text { Grant }\end{array}$ & 0.9 & 22,000 & 1.0 & 20,200 & 1.0 & 25,000 & 1.0 & 25,000 \\
\hline $\begin{array}{l}\text { Travel to } \\
\text { Interview } \\
\text { Scheme }\end{array}$ & & & & & & & & \\
\hline
\end{tabular}

Source: DfEE Departmental Report, London, The Stationery Office Limited, April 2000, p.135. 
The ES also provides a comprehensive account management service to large international and multi-site employers who prefer to deal with ES on a national or regional basis. Many ES services are already delivered electronically to both jobseekers and employers, via telephone, computer or television. Examples of such services mentioned at the Jobcentre in London include:

- Employment Service Direct, introduced in January 1999, where job seekers and employers can ring a national number charged at a local rate to gain access to details of job vacancies nation-wide.

- The ES's Peterlee Call Centre which enables employers throughout the North East to notify vacancies by e-mail or through a single telephone number.

- The ES website ${ }^{18}$ which offers a range of job vacancies as well as general information about ES programmes, services and performance.

Further, major developments are planned over the course of 2000-2001 through the "Modernising ES Programme". Its aim is to exploit modern technology to enable ES to manage and deliver its services in more accessible, user friendly and effective ways. Under the programme the ES will;

- substantially enhance its core IT system to further improve face to face customer service and to provide a more flexible and dynamic tool to help jobseekers find jobs;

- update the IT system diary to provide a more flexible appointment booking system which allow ES staff to make appointments for colleagues in their office;

- introduce electronic versions of standard forms and letters available on ES staff computer terminals in Jobcentres, to improve both the quality and standard of client communications;

\footnotetext{
${ }^{18}$ For more information see, Employment Service (ES) website at [http://www.employmentservice.gov.uk].
} 
- create an Internet Jobs and CV Bank, as part of a wider Learning and Work Bank being developed jointly with the DfEE which will provide access to all ES's nation-wide job vacancies via the internet;

- begin to introduce touchscreen kiosks into Jobcentres to allow all jobseekers to reach vacancies themselves; and

- introduce a single national telephone number to enable employers to notify their vacancies more easily complementing the ES Direct Service for jobseekers.

Taken together these changes will mean that all of ES's key services will be available to jobseekers and employers by phone and internet as well as through Jobcentres. This will provide radical improvements to the quality and effectiveness of labour market services, enabling the ES to meet the employment needs of the future.

In March 2000 the Prime Minister of Great Britain, Tony Blair announced the creation of a new agency, to be established in 2001-2002, which marks a major step forward in the government's welfare reform programme. The agency will bring together the work of the ES with the services which the Benefits Agency (BA) provides to people of working age, to offer a single point of access for personalised support and advice on looking for work and accessing the benefits system. The new agency will draw upon the experience, skills and expertise already gained by the ES working in partnership with the BA to deliver and improve the range of services to jobseekers and employers. Until the new agency is established, the ES will continue to work closely with the Benefits Agency.

The ES and the BA's planned activities for the future are; ${ }^{19}$

- establishing Closer Working Pilots in ten locations across the country. These will test how staff can work together to deliver seamless front line services to people of working age;

${ }^{19}$ The Employment Service Operational Plan, London, The Employment Service Publication, 2000, p. 39. 
- funding a number of initiatives designed to rationalise ES and BA office accommodation;

- wherever possible continuing to work together to match organisational boundaries to support joint business needs and with those of Local Authorities and other partners;

- further evaluating and developing the closer working for Improved Customer Service initiative. This encourages ES and BA managers to continuously review the service they give to jobseekers;

- building a strategic model of all ES and BA business process to assist in the development of joint service delivery; and

- maintaining a programme of integrated and robust testing of new developments to ensure products and processes are fit for purpose and support enhanced customer service standards.

\section{b. Private Recruitment Agencies in Great Britain}

The recruitment industry is gaining importance in most industrialised countries. Recruitment agencies are strategically important part of Britain's modern service economy. Agencies typically operate in one of three ways: by supplying or finding workers with particular skills for particular sectors; through general operators supplying workers of all kinds within their locality; and through specialist agencies dealing with head-hunting, outplacement or information provision. Common to all is that the agency acts as an intermediary or channel through which parties find each other for the purpose of doing or getting work done.

Figure 4, based on Labour Force Survey, shows that the industry has been growing over the past several years. ${ }^{20}$

${ }^{20}$ U. Hotopp "Recruitment Agencies in the UK", Labour Market Trends, October 2000, London, 2000, pp. 457-463. 
Figure 4: Numbers of Agencies Measured by the Labour Force Survey in Great Britain

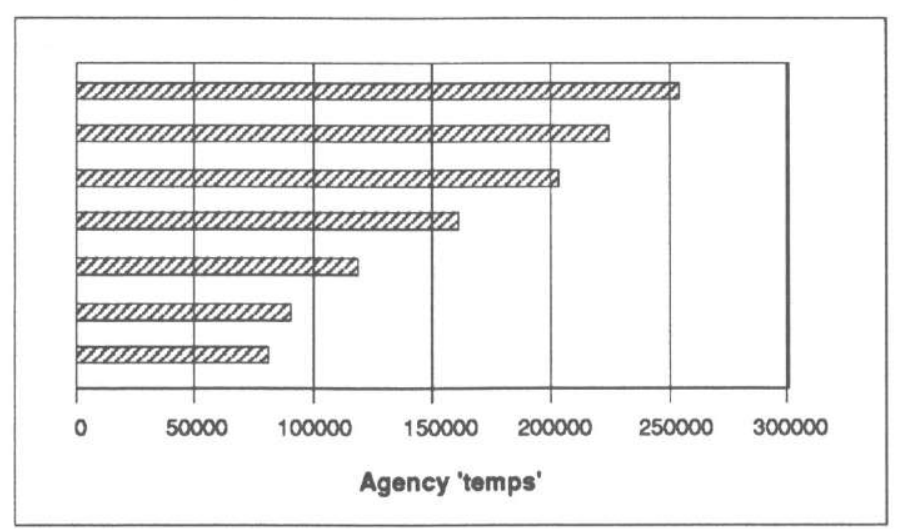

Source: U. Hotopp, "Recruitment Agencies in the UK", Labour Market Trends, October 2000, p. 458.

Figure 5 presents the data provided by Recruitment and Employment Confederation. ${ }^{21}$

Figure 5: Numbers of temporary workers on payroll

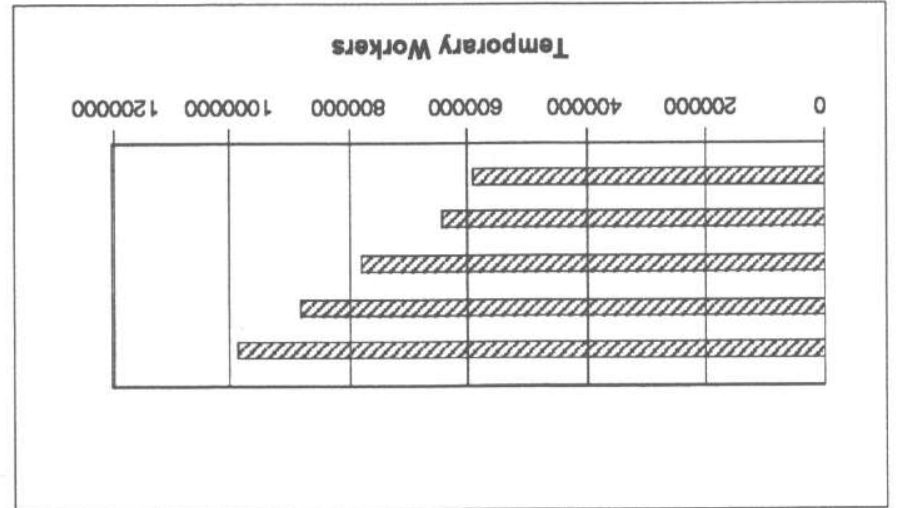

Source: U. Hotopp, "Recruitment Agencies in the UK", Labour Market Trends, October 2000, p. 458.

${ }^{21}$ Formerly the Federation of Recruitment and Employment Services (FRES). For more information see, FRES website at [http://www.fres.co.uk]. 
The sector itself directly employs a workforce of 78.000. Most agencies, however, have less than 10 employees. Agencies with over 100 direct employees account for approximately 15 percent of the industry. Two interviews with the managers of two private recruitment agencies in London (Select and Reed Employment Services ${ }^{22}$ ) were conducted by the author. They both provide temporary and permanent recruitment services and offer a "tailor-made" approach for each client without any charge. Fees are charged from the hirers by these agencies when a temporary worker becomes permanent staff. Detailed information about temporary and permanent recruitment services and activities of "Contract Service Division" of these two private agencies are explained below.

\section{i. Permanent Recruitment Services}

All candidates undergo a strict series of assessments, in-depth interviews and through referencing before reaching the client. Work history, aptitude and personal career needs are ascertained. A minimum of two verbal or written references from previous employers also obtained. Then each candidate is briefed in great detail on the particular job. An in-depth knowledge of the client's organisation, style of operation and company culture are gained by the agency staff. These procedures enables them to inform the candidate accurately and in comprehensive detail about the prospective employer.

Quality control is an important part of their working method. Clients with permanent placements are contacted on the first day of the candidate's work for assessment and at the end of the second, fifth and eight weeks, before they can despatch their Quality Control form.

${ }^{22}$ For more information, contact Select e-mail address: information@select.co.uk, and see Reed Employment website at [http://www.reed.co.uk]. 


\section{ii. Temporary Recruitment Services}

Temporary work requires a special kind of aptitude. Therefore they give particular attention to reliability and personality. Select temporaries are tested, interviewed and referenced as thoroughly as permanent candidates. Furthermore, a maximum of one hour's response to any temporary booking is guaranteed. As a matter of course with every assignment they call to confirm the temporary's arrival and later in the day to check performance. Once the assignment has been completed, they send their Quality Control form to make sure the performance of the temporary, and their handling of the booking came up to the client's expectations. These procedures enable them to maintain the high standards demanded of their temporaries.

\section{iii. Contract Services Division Activities}

This specialist division was established to focus solely on developing partnership agreements with these clients who either undertake a tender process with a view to formalising long-term business associations or seek an innovative solution to a specific project or volume recruitment campaign with a provider of staffing services solutions. Their menu of options is considerable and includes account management, customised invoicing and accounts procedures, together with specific management information reports. Their expertise also includes the implementation and management of totally outsourced projects including assessment centres as well as controlling contracts on a Master Vendor or Sole Supplier basis. Their approach is to utilise the knowledge and expertise of their own internal functions such as IT, Marketing, Personnel and Finance to achieve the highest possible service delivery to their clients. Department of Trade and Industry (DTI) aims to simplify and reduce the number of regulations governing this industry. The existing legislation is nearly 23 years old. There is a proposed regulation which seek to promote labour market flexibility. ${ }^{23}$

${ }^{23}$ Regulation of the Private Recruitment Industry, London, The Department of Trade and Industry Publication, A Consultation Document, 1999. Details of the agency regulations can be found in the DTI website address at [http://www.dti.gov.uk/er/agyreg/index.htm]. 


\section{Conclusion}

In Turkey, the foundation of Employment Organisation is recent. Unfortunately, the services, duties and authority provided by Turkish Employment Organisation are not at the desired level. For this reason, there is a "Reorganisation Project" in TEO. In this context, many services of DfEE can be adopted to the Turkish system. Modern technology can be used for more effective employment services. Helping people to move from welfare into work is also a priority for the Turkish Government. The TEO must be the lead organisation of this programme and work closely with the other government departments. TEO must offer intensive support to find and keep job for the unemployed people from all age (even after 50 years old), people with disability and loneparents. Employment Service Programmes of the DfEE (such as Programme Centres, Jobclubs, Jobplan Workshop, The Travel to Interview Scheme, etc.) can also be adopted to the Turkish employment system. As the unemployment rate is very high in Turkey, private recruitment agencies have to be encouraged by Turkish Government. Then Turkish employment system will be a vital part of a modern welfare state fit for the $21^{\text {st }}$ Century. Customers will benefit from having a service focused on their specific needs and staff will benefit from having common objectives and a shared culture, vision and set of values. 